\title{
Non-Penal Countermeasures Efforts in Supporter Conflict (Study on PSIM vs Persis Conflict)
}

\author{
Laras Astuti', Nyoman Serikat Putra Jaya ${ }^{2}$, R.B Sularto ${ }^{3}$
}

\footnotetext{
${ }^{1}$ Faculty of Law, Universitas Diponegoro, Email: larasastuti76@yahoo.co.id

2 Faculty of Law, Universitas Diponegoro, Email: nyomanspj@lecturer.undip.ac.id

${ }^{3}$ Faculty of Law,Universitas Diponegoro, Email: sulartorb@lecturer.undip.ac.id
}

\begin{tabular}{l}
\hline Info Artikel \\
\hline Received: $2^{\text {nd }}$ March 2021 \\
Accepted: $21^{\text {st }}$ July 2021 \\
Published: $31^{\text {st }}$ July 2021 \\
Keywords: Non Penal Efforts; \\
Social Conflict Management; \\
Sobural Approadh; Supporters \\
Corresponding Author: \\
Laras Astuti, Email: \\
larasastuti76@yahoo.co.id \\
DOI: \\
10.24843/JMHU.2021.v10.i02.p02 \\
\end{tabular}

\begin{abstract}
The conflict between PSIM Yogyakarta and PERSIS Solo supporters is a conflict that has been going on for a long time. These conflicts often cause casualties and damage to public facilities. Severe sanctions do not frighten supporters and a deterrent to take anarchic actions. To overcome this, preventive efforts (non-penal) can be used as an alternative in resolving supporter conflicts. Through socio-legal research, this paper aims to find out more about non-penal countermeasures based on an analysis of the factors that cause supporter conflict. The results of the study, it is known that non-penal countermeasures can be done by emphasizing the efforts of the supporter development process as part of the criminal politics of prevention without punishment. The coaching process is based on three factors that cause supporting conflicts, namely based on the nature, position of the actors, and diversity of society. The police and supporter also have a strategic role in preventing criminal acts to minimize the occurrence of clashes between supporters. These roles indude providing security personnel, conducting sweeping, and coordinating between related parties.
\end{abstract}

\section{Introduction}

"Yes, it is better not to have football in Yogya, because it will only build uncivilized people". ${ }^{1}$ This statement was made by the Governor of the Special Region of Yogyakarta, Sri Sultan Hamengkubuwono $X$ after the chaos that occurred at the Mandala Krida Stadium between PSIM Yogyakarta and PERSIS Solo in the league match 2 Monday, October 21, 2019. Yogyakarta is known as a city that is safe, loves peace, became tense with the conflict of supporter that occurred in the region. It is not an exaggeration if the statement raises the opinion that the conflict of supporter and the chaos that occurs can build a bad supporter culture because supporter anarchism always occurs. The supporter conflict that occurred between the two teams seemed to be a descending conflict because it had been happening for a long time.

The chaos that occurred in the match did not necessarily make Sri Sultan Hamengkubowono $X$ refuse to give permission for the football match to be held in the Yogyakarta area. In the future, it is necessary to conduct a joint evaluation so that the

\footnotetext{
${ }^{1}$ Tegar Paramartha, "Buntut Kerusuhan PSIM Vs Persis, Sri Sultan Hamengku Buwono X Ancam Setop Sepakbola Di Yogyakarta," Goal.com, 2019.
} 
implementation of football runs well and smoothly which takes place every season. Because basically, a football match that only ends in violence will never bring any benefits. ${ }^{2}$

The chaos that occurred in the match between PSIM Yogyakarta and PERSIS Solo was caused by the host's dissatisfaction with the results of the match which caused their team to lose. The dissatisfaction is carried out by carrying out various anarchic actions, such as: chasing players, intimidating, damaging stadium facilities and vehicles, even persecution. ${ }^{3}$ The variety of supporter anarchism is a form of criminal act, so that if an individual supporter commits a criminal act, it will be processed in accordance with Indonesian criminal law or also referred to application of criminal law (penal).

Criminal law through the Criminal Code as a penal (repressive) effort to resolve crime has always been used in resolving supporter anarchism. In fact, the sports law especially football, criminal acts happen not only be committed by supporter, but also on a broader level many parties can commit various criminal acts, such as league organizers, players, referees, and other related parties. Starting from the election of the PSSI general chairman, which is full of elements of interest, other problems in managing football that have been carried out so far have also inflict various problems of a criminal nature, such as football mafia, bribery, score-fixing, 4 to inconsistencies in overcoming the classic problems of football supporter anarchism. Supporter anarchism is one of the interesting problems to be studied considering the many very complex problems that occur in it.

In fact, the phenomenon of supporter conflict continues to occur even though criminal law is always at the forefront to resolve crimes committed by supporter. The supporter conflict between PSIM and PERSIS is not only the first time has occurred and is not the only group of supporters involved in supporter anarchism. Supporter conflicts with a large mass base such as PERSIJA, PERSIB, AREMA, PERSEBAYA, PSS, were previously involved in various supporter conflicts that led to acts of anarchism. Finally, several PERSIB supporter were sentenced for violating the provisions of Article 170 of the Criminal Code in the PERSIJA and PERSIB matches in Bandung.

Article 170 of the Criminal Code is mostly used to penalize several supporters who commit anarchism together by hitting or using other forms of violence against other supporters. Not infrequently the beatings cause the death of another supporter. A maximum prison sentence of 12 years awaits the perpetrators of the beating. The criminal sanctions that will be given to the perpetrators in fact do not bring a deterrent effect and become a lesson for other supporters. The fact is, there are still many supporters who die in every football league organization. From 1994 to 2018, there were 76 supporters who died because of the supporter conflict that occurred, 22 of which were caused by beatings. ${ }^{5}$

\footnotetext{
${ }^{2}$ Ibid.

${ }^{3}$ Vincentius Atmaja, “Laga PSIM Yogyakarta vs Persis Solo Benujung Ricuh,” liputan6, 2019. (Accessed January 5, 2021)

${ }^{4}$ Eko Noer Kristiyanto, "Pengaturan Skor Sepak Bola Dan Ketidakma(Mp)Uan Penegak Hukum,” Jurnal RechtsVinding Onlin, 2015, 1-3.

${ }^{5}$ Tamtomo. A.B. (2018). Indografik: Data Suporter Tewas, Catatan Hitam Dari Lapangan Hijau. Available from https $\cdot /$ bola.kompas .com/read/2018/09/26/16580438/infografik-data-s uporter-tewas catatan-hitam-dari-lapangan-hijau (Accessed January 5, 2021).
} 
There are still many supporters who have died because of this conflict. This is because the penal countermeasure efforts used so far are not effective. This happens because criminal law is a small part of the means social control that is impossible to overcome the problem of crime as a very complex humanitarian and social problem. Moreover, so far, the application of criminal law to resolve crime is more about curing symptoms or symptomatic treatment rather than focusing on factors that eliminate the causes of crime or causative treatment. This is reflected in the implementation of criminal sanctions that have so far been imposed which only overcome the symptoms or consequences of crime and not as a remedy to overcome the causes of the crime. ${ }^{6}$

This research is very important to be investigated because the resolution of the conflict of supporter so far through punishment (penal) has not given maximum results in overcoming the conflict of supporter. Non-penal countermeasure efforts or noncriminal settlements can be used as an alternative to overcome the supporter conflicts that have occurred so far. This effort can be started by knowing in advance the factors that cause supporter conflict. These factors will be used as a basis for consideration to form non-penal conflict countermeasures efforts.

This study of the conflict between football supporter in Indonesia is indeed not the first time that it has attracted the attention of academics or practitioners to be investigated. In previous studies or research, researchers found several articles in journals, each of which has its own characteristics that distinguish this research from previous studies or research. A previous study or research related to supporter anarchism was written by Sulistiyono entitled "Preventing and Reducing Football Violence through Physical Education, Sports and Health." As for the results, physical and spiritual education can be used as a tool to prevent football violence by focusing on the affective domain there is a value of sportsmanship or a sense of fair play as one solution that can be done. Of course, this can be done by involving teachers and students in their learning. ${ }^{7}$

A previous study or research was also written by Filosa Gita Sukmono entitled "The Rivalry of Aremania and Bonekmania (Unraveling the Conflict of Supporter through the "dark side" of Intercultural Communication". This paper describes the rivalry that occurs between aremania and fanatical bonekmania it is studied from a trans-cultural perspective, that the rivalry of the two supporters has exceeded the boundaries of hostility in terms of stereotypes and prejudice, ethnocentrism, and racism. ${ }^{8}$

The last research was written by Yusuf Adam Hilman entitled "Motives and Institutional Conflicts of Football Supporters in AREMANIA". This paper describes the ongoing conflict between Aremania and Bonekmania, not about the problem false and true, but how the supporter interprets the conflict, as a reaction to various related events. These efforts must be carried out continuously, involving all parties including the seniors who are elders in the supporters so that the peaceful efforts made are not in vain. ${ }^{9}$

\footnotetext{
${ }^{6}$ Barda Nawawi Arief, “Aspek Kebijakan Penegakan Dan Pengembangan Hukum Pidana” (Ed. Revisi, Citra Aditya Bakti, Bandung, 2005).p.74.

${ }^{7}$ Sulistiyono, "Mencegah Dan Mengurangi Kekeras an Sepakbola Melalui Pendidikan Jasmani Olahraga Dan Kesehatan," Jurnal Pendidikan Jasmani Indonesia 6, no. 2 (2000): 32-38.

8 "Rivalitas Aremania Dan Bonekmania (Mengurai Konflik Suporter Melalui 'Sisi Gelap' Komunikasi Antar Budaya),” accessed July 17, 2021, http://repository.umy.ac.id/handle/123456789/2195.

${ }^{9}$ Yusuf Adam Hilman, Motif Dan Kelembagaan Konflik Supporter Sepak Bola Pada AREMANIA (An 1mage, 2017).
} 
From previous research studies, the current study that will be studied by researchers has differences. The previous study was not specific and focused more on the prolonged conflict experienced by the supporter and was not accompanied by an analysis of the factors causing the conflict. Meanwhile, the study that will be studied in this study focuses more on the factors causing the conflict of supporter and formulating non-penal countermeasures that are analyzed in a multidisciplinary manner.

\section{Research Methods}

This is a socio-legal research in the form of empirical research oriented to the discovery of theories regarding the process of occurrence and operation of law in society or investigating the relationship between law and other social phenomena. Socio-legal research aims to describe phenomena with facts that occur in people's lives which are always dynamic, interact and relate to one another. Sources of data in this study are divided into primary data derived from interviews, and secondary data that is useful to complement primary data consisting of several normative studies and literature reviews. Data were collected by observing and interviewing several PSIM supporters. The data obtained were analyzed using a flow model of analysis through a concept, analysis, and comparison approach.

\section{Results and Discussion}

\subsection{Supporter Conflict in terms of Social Conflict and Criminology}

Conflict is something that always found in every day. Conflict as a manifestation of differences, squabbles, disputes, and conflicts involving individuals with individuals, as well as individuals with the surrounding environment. The purpose of the conflict is to show existence as the strongest individual or group by weakening the opposing party. Of course, this is done without regard to the rules or applicable laws. This conflict is known as social conflict. 10

Differences in the conflict will provoke opposing attitudes between the two parties where one party will look the other party as an opponent who hinders achieving a goal. It is not surprising that conflict is always accompanied by threats of violence. 11 This is done as a form of struggle to gain recognition and power which can be interpreted as a conflict of power and interest between one group and another in the process of competing for relatively limited social resources (economic, political, social, and cultural).12

One of the subjects who are prone to conflict are supporter. The term supporter is often heard in various sports and is identified as a figure who provides moral and non-moral support for the team they support. Football is a sport that has the most supporters. The number of football competitions held not only at the international level but also at the

\footnotetext{
${ }^{10}$ Irving M. Zeitlin, Memahami Kembali Sosiologi (Yogyakarta: Gadjah Mada University Press, 1998).p.156.

${ }^{11}$ Suyanto, B \& Narwoko, J.D. (2005). Sosiologi Teks Pengantar Dan Terapan. Jakarta: Kencana Prenada Media.p.68

${ }^{12}$ Robert Lawang, "Buku Materi Pokok Pengantar Sosiologi," Jakarta: Universitas Terbuka, 1994.p.53
} 
local level has also created a group of supporters who will always support the football team. ${ }^{13}$

The existence of this group of supporters is not only seen from the large number of supporters in the stadium, but also spread throughout the area. Almost all regions have their own group of supporters and are known for their high loyalty. They have slogans, national anthems, chants, special choreography as a form of support for the football team in every match. ${ }^{14}$ Especially supporter of big football teams, such as PSIM Jogja and PERSIS Solo.

The behavior of football supporter is a social behavior that comes from the actions of supporter and occur in the environment, it causes consequences or changes to subsequent behavior. ${ }^{15}$ This social behavior led to the conflict between supporter and make supporter to commit criminal acts that are threatened in the criminal law code. There are many kinds of criminal acts committed by supporter because the conflict, such as traffic violations, beatings, persecution, destruction of public facilities including stadium facilities, terrorizing, intimidating and provoking SARA, even from these actions it can cause other supporters to die.

So far, the process of resolving conflict between supporter is mostly done through by KUHP or criminal law code. Law enforcement officers not difficult to find and determine what articles can be applied to supporter of anarchism. The articles commonly used against supporters of anarchism are Article 170 of the Criminal Code (Beating), Article 338 of the Criminal Code (Murder), Article 340 of the Criminal Code (Premeditated Murder), Articles 351 to 355 of the Criminal Code (Persecution) and Article 358 of the Criminal Code (gang fights/brawls). The characteristic of the anarchism supporter is done collectively does not make the perpetrators accountable for their actions collectively, although anarchism supporter is often identified with collective violence as contained in Article 170 of the Criminal Code regarding beatings and Article 358 of the Criminal Code regarding collective fights/brawls, the perpetrators are responsible for their actions individually with guidelines the severe or light the punishment obtained is determined by each role and the attitude of the perpetrator which can differ from one perpetrator to another during the examination process in court.

Unfortunately, the penal solution or repressive does not have any influence or become a lesson for other supporters not to conflict with each other, thus led to various anarchism. So far, the use of criminal law to countermeasures crime is "kurieren am symptom", therefore criminal law is only "symptomatic treatment" and not "causative treatment". 16 There needs to be an effort to overcome the supporter conflict by finding the basic problem and treating the problem to create a wiser and better supporter.

Moreover, the various conflicts of supporter so far and anarchism that have been carried out have made the supporter known as bad supporter, anarchist supporter, and unsupportive supporter. The labeling theory explain that behavior supporter like that is a negative labeling because it makes supporter not introspect on the labeling given

\footnotetext{
${ }^{13}$ Istiqomah Wibowo Indria Hapsari, "Fanatisme Dan Agresivitas Supporter Klub Sepak Bola," Jurnal Psikologi 8, no. 1 (2015): 52-53.

${ }^{14}$ Wahyudi Hari, "The Land Of Hooligans" (Jogjakarta: Garasi, 2009).p.101-104

${ }^{15}$ Retno Wulandari Hariyadi Dewi Suci Kusuma Astuti, "Kajian Kriminologis Aksi Kekerasaan Suporter Sepakbola," Jurnal Recidive 2, no. 2 (2013): 156.

${ }^{16}$ Arief, "Aspek Kebijakan Penegakan Dan Pengembangan Hukum Pidana."
} 
but proves its power and influence negatively and creates fear and anxiety for the surrounding community. Labeling cause an identity is given to an individual or a group deviates from behavior that is not in accordance with the norms in society. ${ }^{17}$

Supporter social conflicts and the labeling given to supporter can also be studied through a sobural approach. This approach is known as an approach with characteristics of the Indonesian nation which was introduced by J.E Sahetapy and a new study known in criminology to find out the causes of crime through social, cultural aspects and structural factors of society. ${ }^{18}$ The sobural aspects can be understood such as, social values in society are formed from cultural values and social values, adherence to the contextualization correlation of social reality, and seeing the existence of human existence as God's creation. ${ }^{19}$

Supporter conflict is a form of social conflict that occurs through a social process. The social process itself can be combined (associative process) and social process that divorces (dissociative process). The associative social process is directed at the realization of the values of social justice, love, harmony, and solidarity, which is also called a positive process. While the dissociative social process is directed at the creation of negative or asocial values, such as hatred, hostility, egoism, also called the disunity and so on.20

The social process can be a positive process if the group of supporters always provides total support, bring solidarity even though they have different backgrounds, and upholds the values of sportsmanship in the sense of being able to position themselves and have good attitudes when the soccer team wins or loses. This can bring solidarity and healthy relationship between supporters to make the supporters a good supporter. However, this social process can also act as a negative process because excessive fanaticism creates provocative supporters. These supporters can instigate other supporters to cause collective violence because someone can easily be provoked, explode their emotions, and allow them to carry out a sequence of acts anarchism together. ${ }^{21}$ Supporters will always be like this if there is still a wrong perception in providing support, so that supporters always realize themselves by acting without rules and without being controlled.22

Identification of the supporter group is very easy; they can be recognized by the attributes they wear when supporting their football team playing. It is different when identifying individual supporter who are provocateurs to ignite emotions and influence other supporters, it is not easy because the security system in Indonesia cannot quickly identify the person who carried out the provocation. This provocation is carried out by violating existing norms, taking actions that cause discomfort to other groups of supporters or to postpone matches which will eventually lead to criminal acts.

\footnotetext{
${ }^{17}$ Erianjoni, "Pelabelan Orang Minangkabau Pada Pelaku Penyimpangan Sosial : Studi Kasus Pada Dua Nagari Di Sumatera Barat," Jurnal Humanus XIV, no. 1 (2015): 32.

${ }^{18}$ Sahetapy, E. \& Sahetapy, J.E (2005). Pisau Analisis Kriminologi. Bandung: Citra Aditya Bakti.p.24

${ }^{19}$ Hwian Christianto, "Revege Pom Sebagai Kejahatan Kesusilaan Khusus: Perspektif Sobural," Veritas et Justitia 3, no. 2 (2017): 299-326.

${ }^{20}$ Soetomo, Masalah Sosial Dan Pembangunan (Jakarta: Dunia Pustaka Jaya, 1995).p.77

${ }^{21}$ Yustinus Sukarmin, "Tindakan Vandalisme Suporter Sepakbola : Penyebab Dan Penanggulangannya" (Yogyakarta, 2010). (Accessed January 7, 2021)

${ }^{22}$ Bimo Walgito, Psikologi Sosial : Suatu Pengantar (Yogyakarta: Andi Offset, 2003).p.121
} 


\subsection{Analysis of Non-Penal Countermeasures Efforts to Resolve Supporter Conflict through Social Conflict Approach and Criminology}

Supporters consist of people who come from various backgrounds and different environments. Differences in background will occur in a group, resulting in the assimilation of nature, characters, and habits that are dangerous if there is no understanding of sportsmanship values. This character tends to bring supporter into a negative and fanatical side when providing support for their football club. This will make conflicts between supporters unavoidable.

One of the supporter conflicts occurred between PSIM Yogyakarta and PERSIS Solo in the continuation of the football league Divisi Dua, in 2019. The incident involved several PSIM Yogyakarta supporters who carried out anarchic actions, starting with throwing objects at the soccer field when PSIM Yogyakarta lost against PERSIS Solo. The action continued to the stadium by involving security forces, even spreading to the streets, causing congestion, and disturbing the surrounding community and other road users.

The consequences of these actions are certainly not only disserved to football clubs and supporter clubs, but also are felt by the wider community who do not follow the match or know the previous background events. As experienced by Pak Wira, the owner of a helmet shop around Jalan Abu Bakar Ali, which is one of the main access roads to the Mandala Krida Stadium, felt noisy and disturbed by the convoy carried out by groups of supporters. ${ }^{23}$ Not only that, the label for the match between PSIM Yogyakarta and PERSIS Solo is always considered a match that will end in chaos, considering that the relationship between the two clubs has been known to be inharmonious from the past, thus creating an atmosphere of fear and discomfort for anyone who is close to the supporters.

The atmosphere of fear, anxiety, anger, and trauma is felt by the surrounding community and road users, with the hope that they will not become the object of the supporter anger. Moreover, the conflict that occurred after the PSIM Yogyakarta and PERSIS Solo matches caused traffic jams at the Klaten Yogyakarta border around Prambanan Temple. Not only that, the impact of the conflict also caused several journalists covering the match to be intimidated by supporter. ${ }^{24}$

The labeling of supporters does not only as a group that can carry out various anarchic actions, but also commits various traffic violations. One of the things always do the supporter convoy without equipped complete driving attributes, such as not having a driver's license, using a modified exhaust, and not wearing a helmet. This was confirmed by one PSIM Yogyakarta supporter with the initials IY, who said that often convoy activities were carried out without wearing a helmet, assuming the distance from the meeting point to the Mandala Krida Stadium was not that far. ${ }^{25}$ Whereas according to traffic law the use of helmets is mandatory regardless of near or far.

Negative stigma is impossible to avoid from these actions. Through media coverage, the public tends to feel uncomfortable, distrustful of the supporters, so that they

\footnotetext{
${ }^{23}$ Wira, "Hasil Wawancara Dengan Salah Satu Warga Kota Baru (Pak Wira)" (2019).

24 "Ricuh PSIM vs Pers is: Menjalar Ke Prambanan, Wartawan Jadi Korban - Tirto.ID," accessed July 17, 2021, https ://irto.id/ricuh-psim-vs-pers is-menjalar-ke-prambanan-wartawan-jadi-korbanekax.(Accessed Januari 7, 2021)

${ }^{25}$ IY, "Hasil Wawancara Dengan Salah Satu Suporter PSIM Yogyakarta (IY)" (2019).
} 
always think the supporter is just an irresponsible people, anarchic, deviant, dangerous individuals who can do everything they can to show their bigotry towards the club. This stigma must be minimized, with the understanding that not all supporters show their support in an anarchic way.

There are still many supporters who provide positive support. There are even several groups of supporters who get awards. Supporters can show positive support and have a tremendous impact on the existence of a football club. The atmosphere brought by the supporter can attract anyone who sees it, considering that in a football match organization there are always many people with various types and motives.

Supporter anarchism can be reviewed through crime prevention policies or commonly known as "Criminal Politics". Crime prevention efforts can be taken by:26

1. Criminal Law Application

2. Prevention Without Punishment

3. Influencing Views of Society on Crime and Punishment/Mass Media

According to Marc Ancel, criminal politics is the rational organization of the control of crime by society. G. Peter Hoefnagels strengthens this definition by stating that criminal policy is the rational organization of the social reaction to crime. This means that criminal politics can be formulated as a rational effort from the community in dealing with criminal acts. 27

Based on the criminal politics above, the pattern of resolving the anarchism of supporters in this analysis is no longer only seen from its application, how criminal law works (KUHP) but must be seen from something bigger than that through prevention efforts or prevention without punishment. The sanctions that have been given so far have not given maximum results in efforts to prevent and deter the anarchism of football supporter being carried out. Resolving this supporter anarchism must begin with a critical study of the causes to preventive efforts. Why does this culture of anarchism of supporters continue to occur, what is the cause and how to overcome the problem?

Eliminating the negative stigma about anarchism supporter can be done by knowing the factors causing the conflict of supporter so that suitable non-penal countermeasures can be found. The factors that cause supporter conflict can be seen in the following picture:

\footnotetext{
${ }^{26}$ Barda Nawawi Arief, Kebijakan Legislatif Dalam Penanggulangan Kejahatan Dengan Pidana Penjara (Semarang: Universitas Diponegoro, 2000).p.47.

${ }^{27}$ Barda Nawawi Arief, Bunga Rampai Kebijakan Hukum Pidana : Perkembangan Penyusunan Konsep KUHP Baru (Jakarta: Kencana Prenada Media, 2011).p.4
} 
Picture 1.

Factors Causing Supporter Conflict

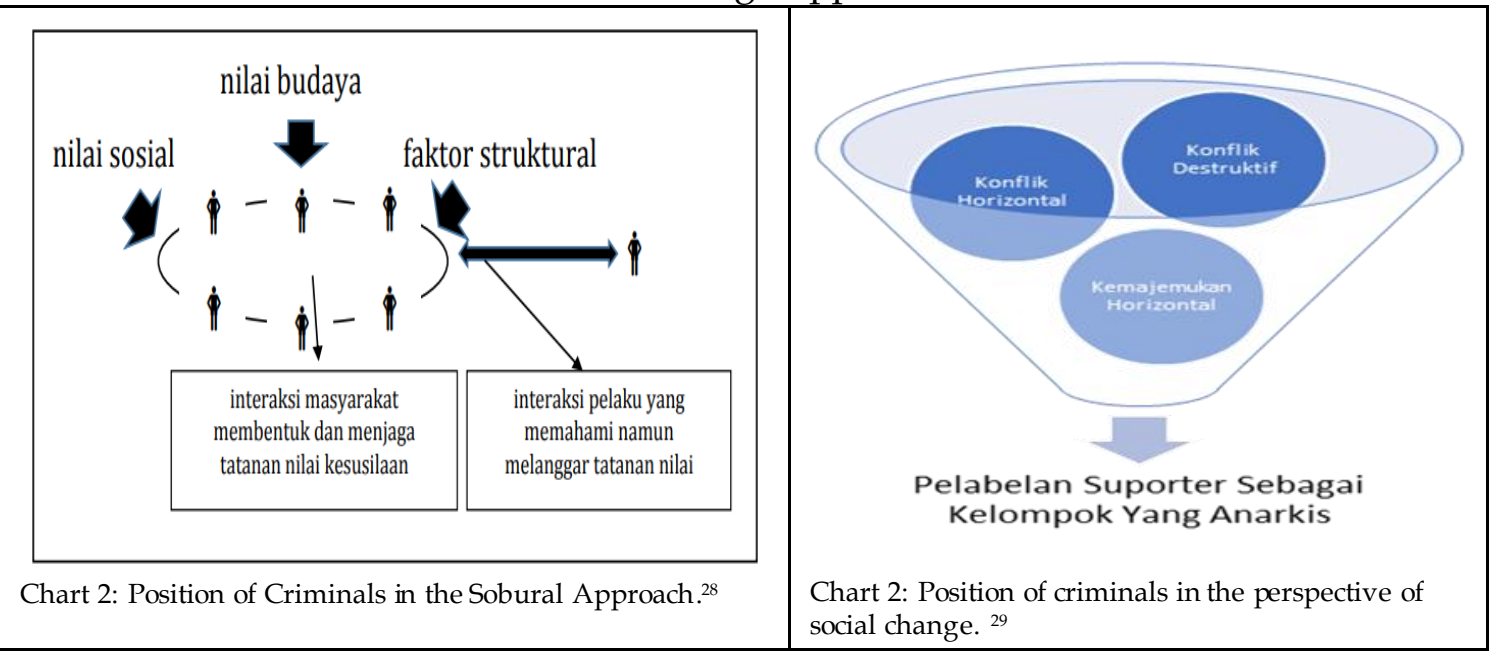

Based on the picture above, non-penal countermeasures can be done by knowing the factors that cause conflict first. The analysis can be explained as follows:

1) Based on the Nature

This factor is called destructive conflict. These factors occur because of feelings of displeasure, resentment, and hatred that are continuously transmitted or inherited in a group of supporters to other groups. This conflict is always accompanied by physical clashes that can cause other groups to be injured, even capable of taking lives, property, and destroying existing public facilities.

The sobural approach in analyzing based on the nature can be seen from the social value, namely the nature of the conflict carried out by supporters. This value is manifested by feeling that they are a greater group than other groups. Rivalry between supporters is not a new thing in Indonesia. In fact, often the rivalry that occurs is caused by conflicts of interest between generations. The paradigm must be change in providing support so that there is no excessive fanaticism, especially if it leads to negative things.

Non-penal countermeasures by looking at the factors causing the conflict of supporter based on their nature can be overcome with the awareness of the supporters. This awareness can be done by eliminating arrogance, communalism, or negative loyal friends, having good emotional management so that they are not easily provoked by their emotions. Education and socialization to supporters can be done by instilling the values of fair play and upholding sportsmanship. This education must be carried out by involving all parties who play a role in the organization of football and cannot be carried out by burdening only one party. There must be a good synergy between groups of supporters, police, organizers, PSSI, and clubs.

\footnotetext{
${ }^{28}$ Christianto, "Revege Porn Sebagai Kejahatan Kesusilaan Khusus: Perspektif Sobural." Op.cit.p.315

${ }^{29}$ Robert H Lauer, "Perspektif Tentang Perubahan Sosial," Jakarta: Rineka Cipta, 1993. Jakarta: Rineka Cipta. p.98
} 


\section{2) Based on the Position of Actors}

This factor is called horizontal conflict. These factors always involve individuals or groups with the same position. This equal position shows the existence of an excessive solidarity with all members so that if one or two people in the group act, are hurt, or are involved in a complicated problem, then members of the other group will participate in helping even with violence.

This solidarity is not only at the level between members of the supporter group but includes football players and organizing matches. It is known that supporter conflict occurred at the Mandala Krida Stadium in the match between PSIM Yogyakarta and PERSIS Solo, was motivated by the dissatisfaction of PSIM Yogyakarta supporter with the process and results of the match. It started with supporter PSIM Yogyakarta who did not accept it because one of the PERSIS Solo players was trying to spin out time and with the action of a kick to Dedi Cahyadi (PERSIS Solo player) carried out by Ahmad Hisyam Tolle (PSIM Yogyakarta player) so that the referee was rewarded with a red card. The incident then triggered the emotions of PSIM Yogyakarta supporters to throw objects into the field and enter the field to intimidate PERSIS Solo players.

The analysis of the cause's supporter conflict carried out by PSIM Yogyakarta supporters, occurred because of excessive solidarity to maintain the cohesiveness of the group. This excessive solidarity was manifested in several actions, such as when this PSIM Yogyakarta supporter held a convoy activity, where most of his followers were students from the age of 13 to 17 years. PSIM Yogyakarta is the oldest football club in the Special Region of Yogyakarta and has a supporter base known as Brayat Jogja Mataram Utama Sejati or Brajamusti with more than 15,000 registered supporters in the Yogyakarta City area. ${ }^{30}$ Together this group of supporters feel strong, not afraid of anything, and ready to support each other, the other members are ready to help regardless of right and wrong. For example, in traffic violations, this large group of PSIM Yogyakarta supporters are not afraid to violate road signs, drive without complete attributes, or disturb other road users or the surrounding community. They feel strong because they are together and will fight back if they are prevented or rejected.

Another example, in the chaos caused by the defeat of PSIM Yogyakarta, made its supporters do sweeping as a form of anger towards PERSIS Solo supporters and motorcycles with AD plates. This was done by PSIM Yogyakarta supporters by taking to the streets and intimidating anyone driving a motorcycle with an AD plate even if they were not part of the group of supporters. Not only intimidation was carried out against PERSIS Solo players and supporters, PSIM Yogyakarta supporters also vandalized Yogyakarta's Mandala Krida stadium facilities, vandalized a police car, and beat up two journalists who were reporting. From these actions, as many as 51 people were arrested by the Yogyakarta Police who were suspected of being the provocateurs or the originators of the conflict. Seeing the number of parties arrested, it can be concluded supporters dared to carried out anarchism if it was together with other members as a form of Excessive solidarity in supporting their favorite club.

\footnotetext{
${ }^{30}$ Niko Anggari, "Hasil W awancara Dengan Sekretaris Jenderal Brajamusti” (2019).
} 
The sobural approach in analyzing actors can be seen from the structural value where supporters consist of various individuals who join create a structured pattern with the same goal, namely providing support to the football team. These individuals interact and understand each other, from the interaction process it can damage the order, norms, and violations of the law. Excessive solidarity that has been formed make individuals always feel right and continue to provide support, even if in the wrong way, for example by carrying out various anarchism that also contribute to supporter conflict.

Non-penal countermeasures efforts by looking at the factors causing the conflict of supporters based on the position of the perpetrators can be overcome by forming a special independent structure or institution that regulates the group of supporters. Belgium is one of the countries that already has an independent institution in managing a structured group of supporters. The institution is known as fan coaching, which in 2012 won an award from UEFA for its contribution to encouraging and maintaining harmony in football matches in stadiums. ${ }^{31}$

The formation of this institution is very possible and responsible for educating supporters in a structured manner and providing an understanding of the values of sportsmanship and the importance of eliminating excessive fanaticism. Of course, the formation of this institution must be initiated by collaborating between parties involved in the management of supporters, for example football clubs, supporter clubs, the ministry of youth and sports and PSSI itself. Education can also be done by including a special chapter in the sports education curriculum related to understanding the values of sportsmanship and fair play so that the character of supporters is formed from an early age and in the future can provide positive support for their favorite football group.

\section{3) Based on the Diversity of Society}

This factor is caused by cultural pluralism. These factors are contained in the structure of society which is based on differences in ethnicity, religion, race, and social diversity in terms of differences in education, work, and profession. Supporters can be formed from various regional structures and social statuses bring their own characteristics that are different from other regions. This brings a tendency for each region to maintain what is characteristic of its habits, so that if the region is unacceptable or different from other groups, it will result in conflict.

The analysis of the cause supporters conflict carried out by the supporters of PSIM Yogyakarta, occurred because most of the members of the supporter group were still teenagers or students who were still in school. School-age children, of course, still have limitations in understanding the situation, are still in the phase of finding their identity, are not yet perfect in distinguishing good and bad things, tend to join in and do not understand the applicable legal regulations. For example, in violation of traffic rules. Many children because they do not know about traffic regulations become traffic violators, such as participating in unauthorized convoys, driving motorized vehicles without official documents, and not using safety supporting

\footnotetext{
${ }^{31}$ UEFA, "Belgium's Fan Coaching Wins Supporters Award," UEFA.com, 2012. (Accessed January 8, 2021).
} 
attributes while driving. This can be prevented by providing socialization and special education to children. Children must know about knowledge of traffic regulations along with an understanding of safety attributes in driving as regulated in Law Number 22 of 2009 concerning Road Traffic and Transportation so that in the future in providing support there will be no more traffic violations. This good understanding will create new habits for children as football supporter in providing positive support even if they must drive a convoy.

The sobural approach in analyzing based on the diversity of society can be seen from the cultural values which are the result of community interactions to form and maintain the order of decency values. As in the habit of violating traffic which occurs because of a habit that has been done before. Children are also easily provoked so that if a fellow supporter commits anarchism or riots, they will be moved to do the same.

Non-penal countermeasures efforts based on diversity of society in the future are not only education on regulations in traffic violations, but also education about cultural differences, different does not mean wrong, different does not mean imposing one is will, different does not mean there must be a gap. Different must strengthen between supporters, with respect for other supporters who come from different regions by stopping intimidation, bullying or SARA and regionalism. Cultural differences should no longer be a regional issue behind the supporter conflict. Bhineka Tunggal Ika needs to be upheld and understood well, all supporters are equal, both support the football group positively. The differences that exist must be used as a strength to support when a team loses and rejoice when a team win.

Based on the analysis of the factors causing the conflict of supporters above, forming a non-penal countermeasure effort in the conflict of supporters can be done by focusing on efforts to foster supporters through criminal politics by emphasizing prevention without punishment. These efforts can be done by instilling the values of fair play, upholding sportsmanship, which can be done by educating or socializing. Other nonpenal efforts make a community of supporters (fan coaching) as a forum for supporters to learn together about positive support, positive solidarity, emotional management, and as a forum to recognize the various structures of supporters who are very diverse due to differences in ethnicity, religion, race, education, occupation, and other backgrounds.

Another non-penal countermeasure effort involves the police as one of the legal structures that have a direct role in supporter conflicts that of ten occur during matches. In the match between PSIM Yogyakarta and PERSIS Solo, Police of Daerah Istimewa Yogyakarta prepared a special scenario to prevent clashes between supporters. These efforts were carried out by increasing the number of security personnel with multiple security statuses, consisting of a combination of the police and the TNI. Security personnel are in place before, during and after the match. The security points are carried out, inside and around the stadium, as well as the main roads that become access for the two supporter teams come and go from the stadium, which includes the Mandala Krida area, Simpang Cendana, Amongrogo from the east, and Simpang Empat Baciro from the north. 
Before and after the match the police also carried out sweeping actions against the supporters. The sweeping process is carried out by confiscation of items that are indeed prohibited from being brought into the match because they have the potential to disturb or trigger chaos among supporter during the match. Sweeping is carried out on supporters before entering the stadium. Even the sweeping process has been carried out in the city's border areas, especially for the guest team supporter.

Dangerous items are often carried by supporters and escape confiscation by security team include liquor, laser pointers, fireworks, carrying wooden sticks, knives, firecrackers, and liquor. The goods were also secured by security officers when doing sweeping. Many factors make it possible for supporter to bring these items into the stadium, such as the absence of strict guard and inspection from security team. Increased security is needed with cooperation between the POLDA DIY, the community of supporters, and the POLSEK Klaten.

Other non-penal countermeasures efforts can also be carried out by the supporter community by carrying out internal coordination before the football match starts. This coordination can be done at least D-1 before the match takes place. The important points discussed in the coordination include direction to minimize the occurrence of chaotic supporters by not being provoked by provocation, direction to provide support in a sporting manner, obeying traffic to not disturbing other road users or the surrounding community, and does not cause a negative stigma against PSIM Yogyakarta supporters. For the coordination to be carried out well, the PSIM Yogyakarta supporter management also cooperates with the match organizing committee and the police. The process of monitoring the behavior of the supporter group is also carried out by the management of the PSIM Yogyakarta supporter group through social media. The social media used include Twitter: @Brajamusti_YK, Facebook: Info Brajamusti and Instagram: @Brajamusti_YK.

\section{Conclusion}

Based on the results of the analysis, it can be concluded that to know the correct nonpenal countermeasure efforts, it is necessary to look at the factors causing the conflict of supporters first. These factors can be analyzed through social conflict theory and sobural approaches which are summarized into three things, namely, based on the nature it is also called destructive conflict or focusing on social values, based on the position of the actor is also called horizontal conflict or focuses on structural values, and based on the diversity of society is also known as cultural pluralism, which focuses on different cultural values that give rise to supporter conflicts. From these three factors, non-penal countermeasures efforts can be formulated by emphasizing the process of fostering supporter as part of criminal politics that is prevention without punishment. The making efforts include instill the value of sportsmanship towards supporters, either through socialization, education, or forming a special institution that handles supporter problems. Non-penal efforts can also be carried out by the Police by providing and increasing the number of security personnel in organizing matches, alerting security personnel at crucial location points, conducting sweeps of supporter, and cooperating with the other police from different area or other related parties. Not only the police, the group of supporters can also help realize appropriate prevention 
efforts (non-penal) by coordinating with their supporter before the match is held. This coordination is needed to provide direction to minimize the chaos of supporters.

\section{Acknowledgments}

The author would like to thank especially Lembaga Penelitian dan Pengabdian University of Muhammadiyah Yogyakarta for funding this research. This research is part of a doctoral grant with a partnership research scheme in the 2019-2020. Thank you to my dissertation supervisor, promoter Professor Nyoman and co-promoter Dr. Sularto, for their guidance and direction, and to Andi Jafits, my research assistant who has helped in finding data in the field. The researcher also thanks to the reviewers who have provided input on the article and to the Journal Magister Hukum University of Udayana for being willing to publish this article.

\section{References}

\section{Book}

Arief, Barda Nawawi. "Aspek Kebijakan Penegakan Dan Pengembangan Hukum Pidana." Ed. Revisi, Citra Aditya Bakti, Bandung, 2005.

- - - Bunga Rampai Kebijakan Hukum Pidana : Perkembangan Penyusunan Konsep KUHP Baru. Jakarta: Kencana Prenada Media, 2011.

- - - Kebijakan Legislatif Dalam Penanggulangan Kejahatan Dengan Pidana Penjara. Semarang: Universitas Diponegoro, 2000.

Lauer, Robert H. "Perspektif Tentang Perubahan Sosial." Jakarta: Rineka Cipta, 1993.

Lawang, Robert. "Buku Materi Pokok Pengantar Sosiologi." Jakarta: Universitas Terbuka, 1994.

Soetomo. Masalah Sosial Dan Pembangunan. Jakarta: Dunia Pustaka Jaya, 1995.

Walgito, Bimo. Psikologi Sosial : Suatu Pengantar. Yogyakarta: Andi Offset, 2003.

Zeitlin, Irving M. Memahami Kembali Sosiologi. Yogyakarta: Gadjah Mada University Press, 1998.

\section{Journal}

Anggari, Niko. "Hasil Wawancara Dengan Sekretaris Jenderal Brajamusti." 2019.

Christianto, Hwian. "Revege Porn Sebagai Kejahatan Kesusilaan Khusus: Perspektif Sobural." Veritas et Justitia 3, no. 2 (2017): 299-326.

Dewi Suci Kusuma Astuti, Retno Wulandari Hariyadi. “Kajian Kriminologis Aksi Kekerasaan Suporter Sepakbola." Jurnal Recidive 2, no. 2 (2013): 156.

Erianjoni. "Pelabelan Orang Minangkabau Pada Pelaku Penyimpangan Sosial : Studi Kasus Pada Dua Nagari Di Sumatera Barat." Jurnal Humanus XIV, no. 1 (2015): 32.

Hari, Wahyudi. “The Land Of Hooligans.” Jogjakarta: Garasi, 2009.

Hilman, Yusuf Adam. Motif Dan Kelembagaan Konflik Supporter Sepak Bola Pada AREMANIA. An1mage, 2017.

Indria Hapsari, Istiqomah Wibowo. “'Fanatisme Dan Agresivitas Supporter Klub Sepak Bola.'” Jurnal Psikologi 8, no. 1 (2015): 52-53.

IY. "Hasil Wawancara Dengan Salah Satu Suporter PSIM Yogyakarta (IY)." 2019.

Kristiyanto, Eko Noer. "Pengaturan Skor Sepak Bola Dan Ketidakma(Mp)Uan Penegak Hukum." Jurnal RechtsVinding Onlin, 2015, 1-3. 
Sukarmin, Yustinus. “Tindakan Vandalisme Suporter Sepakbola : Penyebab Dan Penanggulangannya." Yogyakarta, 2010.

Sulistiyono. "Mencegah Dan Mengurangi Kekerasan Sepakbola Melalui Pendidikan Jasmani Olahraga Dan Kesehatan." Jurnal Pendidikan Jasmani Indonesia 6, no. 2 (2000): 32-38.

UEFA. “Belgium's Fan Coaching Wins Supporters Award.” UEFA.com, 2012.

Wira. "Hasil Wawancara Dengan Salah Satu Warga Kota Baru (Pak Wira)." 2019.

\section{Website}

Atmaja, Vincentius. "Laga PSIM Yogyakarta vs Persis Solo Berujung Ricuh." liputan6, 2019.

"Ricuh PSIM vs Persis: Menjalar Ke Prambanan, Wartawan Jadi Korban - Tirto.ID." Accessed July 17, 2021. https://tirto.id/ricuh-psim-vs-persis-menjalar-keprambanan-wartawan-jadi-korban-ekax.

“Rivalitas Aremania Dan Bonekmania (Mengurai Konflik Suporter Melalui 'Sisi Gelap' Komunikasi Antar Budaya).” Accessed July 17, 2021. http://repository.umy.ac.id/handle/123456789/2195.

Paramartha, Tegar. "Buntut Kerusuhan PSIM Vs Persis, Sri Sultan Hamengku Buwono X Ancam Setop Sepakbola Di Yogyakarta." Goal.com, 2019. 